Research Paper

\title{
Protective Effect of Baicalein on Oxidative Stress-induced DNA Damage and Apoptosis in RT4-D6P2T Schwann Cells
}

\author{
Cheol Park ${ }^{1}$, Eun Ok Choi ${ }^{2,3}$, Gi-Young Kim4, Hye-Jin Hwang ${ }^{5}$, Byung Woo Kim6, Young Hyun Yoo , \\ Hwan Tae Park ${ }^{8}$, Yung Hyun Choi ${ }^{2,3}$
}

1. Department of Molecular Biology, College of Natural Sciences, Dong-eui University, Busan 47340, Republic of Korea

2. Anti-Aging Research Center, Dong-eui University, Busan 47340, Republic of Korea

3. Department of Biochemistry, Dong-eui University College of Korean Medicine, Busan 47227, Republic of Korea

4. Department of Marine Life Sciences, Jeju National University, Jeju 63243, Republic of Korea

5. Department of Food and Nutrition, College of Nursing, Healthcare Sciences \& Human Ecology, Dong-eui University, Busan 47340, Republic of Korea

6. Biopharmaceutical Engineering Major, Division of Applied Bioengineering, College of Engineering, Dong-eui University, Busan 47340, Republic of Korea

7. Department of Anatomy and Cell Biology, Mitochondria Hub Regulation Center, College of Medicine, Dong-A University, Busan 49201, Republic of Korea

8. Department of Physiology, Peripheral Neuropathy Research Center, College of Medicine, Dong-A University, Busan 49201, Republic of Korea

$\square$ Corresponding authors: Hwan Tae Park, Department of Physiology, College of Medicine, Dong-A University, 3-1 Dongdaeshin-dong, Seo-gu, Busan 49201, Republic of Korea, E-mail: phwantae@dau.ac.kr And Yung Hyun Choi, Department of Biochemistry, Dongeui University College of Korean Medicine, 52-57, Yangjeong-ro, Busanjin-gu, Busan 47227, Republic of Korea, E-mail: choiyh@deu.ac.kr

(c) Ivyspring International Publisher. This is an open access article distributed under the terms of the Creative Commons Attribution (CC BY-NC) license (https://creativecommons.org/licenses/by-nc/4.0/). See http://ivyspring.com/terms for full terms and conditions.

Received: 2018.09.04; Accepted: 2018.10.31; Published: 2019.01.01

\begin{abstract}
Background: Due to its high antioxidant activity, baicalein, a kind of flavonoid present in Radical Scutellariae, has various pharmacological effects. However, the protective effect against oxidative stress in Schwann cells, which plays an important role in peripheral neuropathy, has not yet been studied. In this study, the effects of baicalein on hydrogen peroxide $\left(\mathrm{H}_{2} \mathrm{O}_{2}\right)$-induced DNA damage and apoptosis in RT4-D6P2T Schwann cells were evaluated.

Methods: Cell viability assay was performed using MTT assay and colony formation assay. Apoptosis was assessed by flow cytometry analysis and DNA fragmentation assay. The effects on DNA damage and ATP content were analyzed by comet method and luminometer. In addition, changes in protein expression were observed by Western blotting.

Results: Our results show that baicalein significantly inhibits $\mathrm{H}_{2} \mathrm{O}_{2}$-induced cytotoxicity through blocking reactive oxygen species (ROS) generation. We also demonstrate that baicalein is to block $\mathrm{H}_{2} \mathrm{O}_{2}$-induced DNA damage as evidenced by inhibition of DNA tail formation and $\mathrm{yH} 2 \mathrm{AX}$ phosphorylation. Moreover, baicalein significantly attenuated $\mathrm{H}_{2} \mathrm{O}_{2}$-induced apoptosis and mitochondrial dysfunction, and restored inhibition of ATP production. The suppression of apoptosis by baicalein in $\mathrm{H}_{2} \mathrm{O}_{2}$-stimulated cells was associated with reduction of increased $\mathrm{Bax} / \mathrm{Bcl}-2$ ratio, activation of caspase- 9 and -3 , and degradation of poly (ADP-ribose) polymerase.

Conclusions: These results demonstrate that baicalein eliminates $\mathrm{H}_{2} \mathrm{O}_{2}$-induced apoptosis through conservation of mitochondrial function by the removal of ROS. Therefore, it is suggested that baicalein protects Schwann cells from oxidative stress, and may be beneficial for the prevention and treatment of peripheral neuropathy induced by oxidative stress.
\end{abstract}

Key words: Baicalein, Schwann cells, oxidative stress, DNA damage, apoptosis

\section{Introduction}

Oxidative stress, characterized by overwhelming reactive oxygen species (ROS), is a crucial initiating factor in many chronic diseases, including peripheral neuropathy $[1,2]$. Schwann cells are the major glial cells of the peripheral nervous system, and support the normal physiological functions of neurons [3,4]. Mitochondria are the major organelle involved in ROS production by various oxidative stimuli in cells. Although at low levels, ROS plays the role of a second messenger in cellular signal transduction and homeo- 
stasis, the overproduction of ROS damages cellular biomolecules, such as proteins, lipids and nucleic acids, and induces DNA damage and apoptosis in multiple types of cells, including Schwann cells [5-9]. In particular, Schwann cell apoptosis can enhance axonal degeneration, which is an important cause of peripheral neuropathy induction, due to reduced neurotrophic support from Schwann cells $[5,10]$. Therefore, it is essential to inhibit excessive ROS production, in order to maintain the nerve fiber regeneration function of Schwann cells.

Recent data have shown that the antioxidants present in various natural products can be effective in suppressing and curing many diseases, including peripheral neuropathy [11-14]. Among them, baicalein is one of the flavonoids found mainly in Radix Scutellariae, the root of Scutellaria baicalensis Georgi, which has been used in Korea, China, and Japan in the traditional treatment of various diseases $[15,16]$. A number of studies, including our previous results, have shown that baicalein has a variety of pharmacological activities, including anti-inflammatory, antioxidant, and anti-cancer effects [14,17-25]. However, the protective effects and mechanisms of baicalein against oxidative stress in Schwann cells have not yet been studied. Therefore, in this study, we investigate the inhibitory potential of baicalein on cellular injury by oxidative stress using RT4-D6P2T Schwann cells. For this purpose, hydrogen peroxide $\left(\mathrm{H}_{2} \mathrm{O}_{2}\right)$, pro-oxidant agent, is used to mimic the in vitro oxidation, and the effects of baicalein on $\mathrm{H}_{2} \mathrm{O}_{2}$ induced DNA damage and apoptosis are investigated.

\section{Materials and Methods}

\section{Reagents and antibodies}

Dulbecco's Modified Eagle's Medium (DMEM), fetal bovine serum (FBS), and antibiotic mixtures were purchased from WelGENE Inc. (Daegu, Republic of Korea). Baicalein, $\mathrm{H}_{2} \mathrm{O}_{2}$, 3-(4,5-dimethylthiazol-2-yl)2,5-diphenyltetrazolium bromide (MTT), N-acetyl cysteine (NAC), 5,6-carboxy-2',7'-dichlorofluorescin diacetate (DCF-DA), propidium iodide (PI), 5, 5',6,6'tetrachloro-1,1',3,3'-tetraethyl-imidacarbocyanine iodide (JC-1), ethidium bromide (EtBr), 4',6-diamidino-2-phenylindole (DAPI), and annexin V-fluorescein isothiocyanate (FITC) were obtained from SigmaAldrich Chemical Co. (St. Louis, MO, USA). Bio-Rad protein assay kit and mitochondrial protein isolation kit were purchased from Bio-Rad Lab (Hercules, CA, USA) and Active Motif (Carlsbad, CA, USA), respectively. Polyvinylidene difluoride (PVDF) membranes and enhanced chemiluminescence (ECL) solution were obtained from Schleicher and Schuell (Keene, NH, USA) and Amersham Corp. (Arlington
Heights, IL, USA), respectively. ATP assay kit was purchased from Abcam Inc. (Cambridge, UK). The primary antibodies against actin, Bax, Bcl-2, cytochrome $c$, cytochrome oxidase subunit 4 (COX IV), caspase-9, caspase-3 and poly(ADP-ribose) polymerase (PARP) were purchased from Santa Cruz Biotechnology Inc. (Santa Cruz, CA, USA). Anti-histone variant $\mathrm{H} 2 \mathrm{AX}(\gamma \mathrm{H} 2 \mathrm{AX})$ and $p-\gamma \mathrm{H} 2 \mathrm{AX}$ were obtained from Cell Signaling Technology Inc. (Beverly, MA, USA). Appropriate horseradishperoxidase (HRP)-linked secondary antibodies were purchased from Santa Cruz Biotechnology Inc. All reagents that were not specifically identified were purchased from Sigma-Aldrich Chemical Co.

\section{Cell culture and baicalein treatment}

The immortalized human vestibular schwannoma RT4-D6P2T cells were kindly provided by Dr. Hwan Tae Park (Department of Physiology, College of Medicine, Dong-A University, Busan, Republic of Korea). The cells were cultured in DMEM containing $10 \% \mathrm{FBS}$ and $100 \mathrm{U} / \mathrm{ml}$ penicillin and streptomycin at $37^{\circ} \mathrm{C}$ in humidified air with $5 \% \mathrm{CO}_{2}$, and were subcultured every three days. Baicalein was dissolved in dimethyl sulfoxide (DMSO), and the final concentrations were adjusted by dilution with a complete culture medium. The final DMSO concentration was $<0.05 \%$ in all experiments (i.e., a non-cytotoxic range).

\section{MTT assay}

For the cell viability study, RT4-D6P2T cells were cultured in 96-well plates at a density of $1 \times 10^{4}$ cells per well. After $24 \mathrm{~h}$ incubation, the cells were treated with various concentrations of baicalein or $\mathrm{H}_{2} \mathrm{O}_{2}(1$ $\mathrm{mM}$ ) alone, or pretreated with different concentrations of baicalein for $1 \mathrm{~h}$ before $\mathrm{H}_{2} \mathrm{O}_{2}$ treatment. After $24 \mathrm{~h}$, the medium was replaced with MTT $(0.5 \mathrm{mg} / \mathrm{ml})$ solution and reacted for $3 \mathrm{~h}$ at $37^{\circ} \mathrm{C}$. The formazan crystals were dissolved by replacing the supernatant with DMSO. After $10 \mathrm{~min}$, the optical density was measured at a wavelength of $540 \mathrm{~nm}$ by enzyme-linked immunosorbent assay (ELISA) microplate reader (Dynatech Laboratories, Chantilly, VA, USA).

\section{Detection of the intracellular ROS levels}

To measure ROS production using DCF-DA, RT4-D6P2T cells were pretreated with $100 \mu \mathrm{M}$ baicalein for $1 \mathrm{~h}$, and then incubated for $1 \mathrm{~h}$ in the presence or absence of $1 \mathrm{mM} \mathrm{H}_{2} \mathrm{O}_{2}$. Following the termination of the treatment period, the cells were stained with 10 $\mu \mathrm{M}$ DCF-DA for $15 \mathrm{~min}$, rinsed twice with phosphate buffered saline (PBS), and then immediately analyzed using a flow cytometer (Becton Dickinson, San Jose, CA, USA) with an excitation wavelength of $480 \mathrm{~nm}$ 
and an emission wavelength of $525 \mathrm{~nm}$.

\section{Comet assay}

To investigate DNA damage using comet assay, the cells were harvested by trypsinization, and mixed with $0.5 \%$ low-melting-point agarose. The mixture was spread on a slide at $37^{\circ} \mathrm{C}$ and solidified using an ice pack for 5 minutes, and then immersed in a lysis solution [2.5 M sodium chloride $(\mathrm{NaCl}), 100 \mathrm{mM}$ Na-ethylenediaminetetraacetic acid (EDTA), $10 \mathrm{mM}$ Tris, $1 \%$ Triton X100, and $10 \%$ DMSO (pH 10)] for $1 \mathrm{~h}$ at $4^{\circ} \mathrm{C}$. After electrophoresis, the slides were rinsed with a neutralizing buffer (0.4 M Tris, $\mathrm{pH}$ 7.5), dehydrated in absolute ethanol at $4^{\circ} \mathrm{C}$, and allowed to dry. After staining the cells with PI solution (20 $\mu \mathrm{g} / \mathrm{ml})$, images were captured by fluorescence microscopy (Carl Zeiss, Oberkochen, Germany) according to the previous method [26].

\section{Protein isolation and Western blot analysis}

To extract whole-cellular proteins, the cells were collected, washed twice with ice-cold PBS, and then lysed using the cell lysis buffer $[25 \mathrm{mM}$ Tris- $\mathrm{Cl}(\mathrm{pH}$ 7.5), $250 \mathrm{mM} \mathrm{NaCl}, 5 \mathrm{mM}$ Na-EDTA, 1 \% nonidet-P40, $1 \mathrm{mM}$ phenylmethylsulfonyl fluoride, and $5 \mathrm{mM}$ dithiothreitol] for $1 \mathrm{~h}$. The mitochondrial and cytosolic proteins were prepared using a mitochondria isolation kit, in accordance with the instructions of the manufacturer. Protein concentration was measured according to the Bio-Rad protein assay kit and the same amount of protein was separated by electrophoresis in sodium dodecyl sulfate (SDS)polyacrylamide gel and then transferred to PVDF membrane. After blocking with 5\% non-fat dry milk for $1 \mathrm{~h}$ at room temperature, the membranes were probed overnight with primary antibodies at $4^{\circ} \mathrm{C}$. The membranes were washed with Tris buffered saline containing $0.1 \%$ Tween- 20 for $5 \mathrm{~min}$, then incubated for $2 \mathrm{~h}$ at room temperature with the corresponding HRP-conjugated secondary antibody, and visualized with ECL solution. Bands were quantified using ImageJ (Ver. 1.46; NIH, Bethesda, MD, USA) and normalized to actin and the ratio was determined.

\section{Detection of nuclear morphological changes}

To observe the nuclear morphological changes, the harvested cells were fixed with $3.7 \%$ paraformaldehyde in PBS for $10 \mathrm{~min}$ at $25^{\circ} \mathrm{C}$. The cells were washed with PBS and stained with DAPI solution $(1 \mathrm{mg} / \mathrm{ml})$ for $10 \mathrm{~min}$ in the dark. After washing with PBS, the morphological changes in the nucleus were examined by fluorescence microscopy at $\times 400$ magnification.

\section{DNA fragmentation assay}

The collected cells were dissolved in lysis buffer
[10 mM Tris- $\mathrm{HCl}$ (pH 7.4), $150 \mathrm{mM} \mathrm{NaCl}, 5 \mathrm{mM}$ EDTA, $0.5 \%$ Triton X-100, and $0.1 \mathrm{mg} / \mathrm{ml}$ proteinase $\mathrm{K}$ ] for $30 \mathrm{~min}$ at room temperature. DNA from the supernatant was extracted by chloroform/phenol/ isoamyl alcohol $(24 / 25 / 1, \mathrm{v} / \mathrm{v} / \mathrm{v})$ and was precipitated by ethanol. DNA was then transferred to $1.5 \%$ agarose gel containing $0.1 \mu \mathrm{g} / \mathrm{ml} \mathrm{EtBr}$, and electrophoresis was carried out at $70 \mathrm{~V}$.

\section{Colony formation assay}

Cells treated with $\mathrm{H}_{2} \mathrm{O}_{2}$ in the presence or absence of baicalein were washed with PBS. The single cell suspensions were prepared by trypsin treatment, and the cells were inoculated on 6-well plates (500 cells/well). The cells were further cultured for two weeks to form colonies. The colonies were fixed with $3.7 \%$ paraformaldehyde, and stained with a $0.1 \%$ purple-violet solution for $10 \mathrm{~min}$. After washing by PBS, the cell colonies were photographed under inverted microscopy (Carl Zeiss).

\section{Detection of apoptosis by annexin $\mathbf{V}$ staining}

Following the termination of treatment, the cells were harvested and suspension was made in binding buffer (Becton Dickinson). And then, the staining of the cells was conducted using an Annexin V-FITC Apoptosis Detection Kit (Becton Dickinson) for $20 \mathrm{~min}$ in the dark, according to the manufacturer's instructions. The cells were immediately analyzed from each sample using a flow cytometer, and the degree of apoptosis was quantified as a percentage of the annexin V-positive cells.

\section{Measurement of the mitochondrial membrane potential (MMP)}

The changes in the MMP $(\Delta \psi \mathrm{m})$ were assessed using JC-1, following the manufacturer's protocol. In brief, the collected cells were rinsed with cold PBS, and then stained with $10 \mu \mathrm{M} \mathrm{JC}-1$ for $30 \mathrm{~min}$ at $37^{\circ} \mathrm{C}$ in the dark. After washing with PBS to remove the unbound dye, the green fluorescence intensities from the JC1 monomer and the red fluorescence intensities from the aggregated form of JC1 in the cells were measured by flow cytometry (Becton Dickinson), as recommended by the manufacturer's guidelines.

\section{Measurement of ATP content}

The ATP content of cells cultured with different stimuli was measured lumimetrically using a commercially available ATP assay kit. Briefly, after lysing the cells with the buffer provided, the supernatant was mixed with the reaction buffer at a ratio of 1:10, and measured by GLOMAX luminometer (Promega Co., Madison, WI, USA). Subsequently, the cellular ATP content from three replicate experiments was measured from the ATP 
standard curve, according to the manufacturer's instructions. The results were expressed as percentage, and the ATP content of the untreated control cells was assumed to be $100 \%$.

\section{Statistical analysis}

All the experiments reported in this study were performed independently at least three times. The results are presented as the mean \pm SD. Statistical significance was assessed by one-way ANOVA. A $p$ value of $<0.05$ was considered statistically significant.

\section{Results}

\section{Suppression of $\mathrm{H}_{2} \mathrm{O}_{2}$-induced RT4-D6P2T cell cytotoxicity by baicalein}

To establish the experimental conditions, RT4-D6P2T cells were treated with a wide range of concentrations of baicalein for $24 \mathrm{~h}$, and MTT assay was performed. Figure 1A shows that the cytotoxic effect of baicalein was not induced at concentrations up to $200 \mu \mathrm{M}$, but the cell viability was gradually suppressed at concentrations above $300 \mu \mathrm{M}$, as compared to the control cells that had received no treatment. Therefore, the maximum concentration of baicalein to $100 \mu \mathrm{M}$ was chosen to investigate study the inhibitory effect of baicalein on $\mathrm{H}_{2} \mathrm{O}_{2}$-induced cell damage. Our results indicated that pretreatment with baicalein concentration-dependently prevented the reduction of cell viability in $\mathrm{H}_{2} \mathrm{O}_{2}$-treated cells (Figure 1B). Moreover, $\mathrm{H}_{2} \mathrm{O}_{2}$-induced cell viability reduction was completely suppressed in cells pretreated with an antioxidant NAC, as a positive control (Figure 1B).

\section{Reduction of $\mathrm{H}_{2} \mathrm{O}_{2}$-induced ROS generation by baicalein in RT4-D6P2T cells}

To examine whether the cytoprotective effect of baicalein on oxidative stress in RT4-D6P2T cells was correlated with antioxidant activity, the effect of baicalein on $\mathrm{H}_{2} \mathrm{O}_{2}$-induced excessive ROS production was investigated. Our results showed that the level of ROS gradually increased with the treatment of $\mathrm{H}_{2} \mathrm{O}_{2}$, peaked at $1 \mathrm{~h}$ (data not shown). However, the treatment with baicalein alone did not induce ROS production, and the pretreatment with baicalein effectively attenuated the level of ROS released by $\mathrm{H}_{2} \mathrm{O}_{2}$ treatment (Figure 2A). As in the fluorescence microscope observation, we further confirmed that baicalein had a powerful ROS scavenging effect (Figure 2B). NAC also significantly inhibited the $\mathrm{H}_{2} \mathrm{O}_{2}$-induced production of ROS.

A)

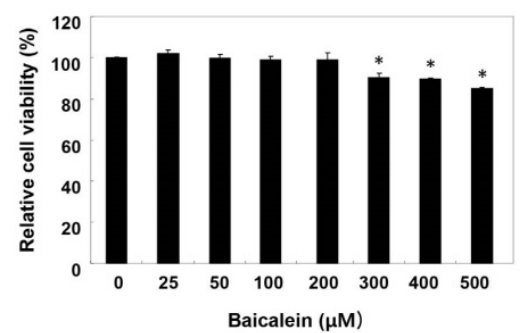

B)

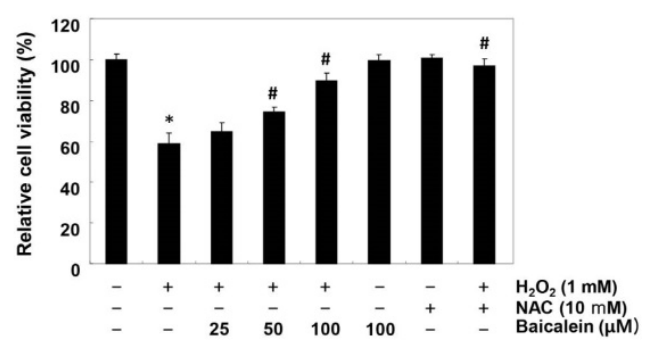

Figure 1. Inhibition of $\mathrm{H}_{2} \mathrm{O}_{2}$-induced cytotoxicity by baicalein in RT4-D6P2T cells. Cells were (A) treated with various concentrations of baicalein for $24 \mathrm{~h}$, or (B) pretreated with or without baicalein for $1 \mathrm{~h}$, and then stimulated with $1 \mathrm{mM} \mathrm{H} \mathrm{H}_{2} \mathrm{O}_{2}$ for $24 \mathrm{~h}$. NAC was used for cells as a positive control. Cell viability was assessed by MTT reduction assay. The results are the mean \pm SD obtained from three independent experiments ( $p<0.05$ compared with the control group, ${ }^{\#}<0.05$ compared with the $\mathrm{H}_{2} \mathrm{O}_{2}$-treated group).

A)

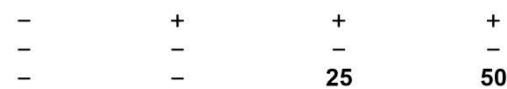

$\begin{array}{lc}+ & + \\ - & - \\ 50 & 100\end{array}$

$\begin{array}{cc}+ & - \\ - & - \\ 100 & 100\end{array}$
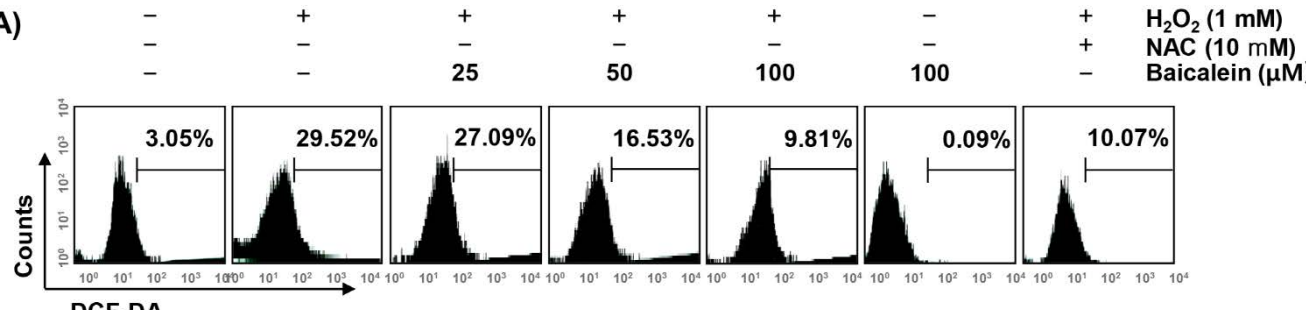

- Baicalein $(\mu \mathrm{M})$

B)
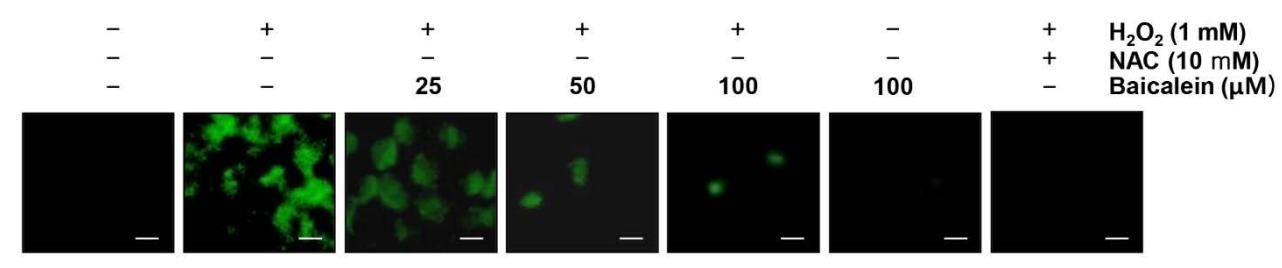

Figure 2. Attenuation of $\mathbf{H}_{2} \mathbf{O}_{2}$-induced ROS generation by baicalein in RT4-D6P2T cells. Cells were pretreated with the indicated concentration of

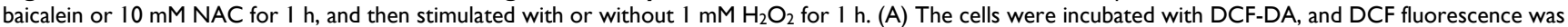
measured by flow cytometry. The values represent the means of two independent experiments. (B) After staining with DCF-DA, images were obtained by fluorescence microscopy (original magnification, $\times 200$ ). These images are representative of at least three independent experiments. Scale bars, $10 \mu \mathrm{m}$. 
A)

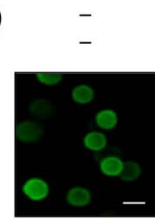

$+$

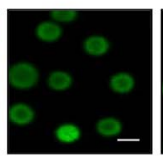

B)

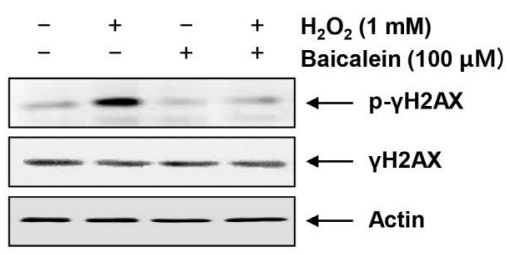

C)

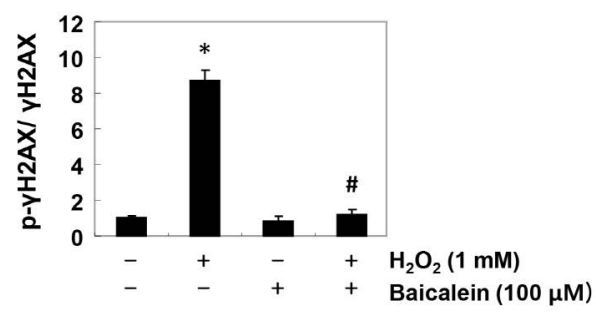

Figure 3. Protection of $\mathrm{H}_{2} \mathrm{O}_{2}$-induced DNA damage by baicalein in RT4-D6P2T cells. Cells were pretreated with $100 \mu \mathrm{M}$ baicalein for $1 \mathrm{~h}$, and then stimulated with or without $1 \mathrm{mM} \mathrm{H} \mathrm{H}_{2}$ for $24 \mathrm{~h}$. (A) To detect cellular DNA damage, the comet assay was performed, and representative photographs of the comets were taken by fluorescence microscopy (original magnification, $\times 200$ ). Scale bars, $10 \mu \mathrm{m}$. (B) Equal amounts of cell lysates were separated on SDS-polyacrylamide gels, and transferred to membranes. The membranes were probed with specific antibodies against $\mathrm{\gamma H} 2 \mathrm{AX}$ and $\mathrm{p}-\mathrm{\gamma H} 2 \mathrm{AX}$, and the proteins were visualized using an $E C L$ detection system. Actin was used as an internal control. (C) Bands were quantified using Image and normalized to actin, and the ratio was determined. Data are expressed as mean $\pm \mathrm{SD}$. All experiments were repeated three times $(\# p<0.05$ in comparison to the control group; $* p<0.05$ compared with the $\mathrm{H}_{2} \mathrm{O}_{2}$ group).

\section{Attenuation of $\mathrm{H}_{2} \mathrm{O}_{2}$-induced DNA damage by baicalein in RT4-D6P2T cells}

To assess whether the inhibitory effects of baicalein on $\mathrm{H}_{2} \mathrm{O}_{2}$-induced cytotoxicity and ROS accumulation were associated with the protection of DNA damage, the comet and immunoblotting assays were performed. As indicated in Figure 3A, no smeared pattern of nuclear DNA was observed in the cells treated with baicalein alone, similar to the control cells. However, DNA tails, which imply DNA damage, were clearly increased in $\mathrm{H}_{2} \mathrm{O}_{2}$-treated cells, while under the baicalein pretreatment conditions, DNA tails were hardly observed. In addition, immunoblotting results showed a marked increase in $\gamma \mathrm{H} 2 \mathrm{AX}$ phosphorylation (at serine 139) in $\mathrm{H}_{2} \mathrm{O}_{2-}$ stimulated cells, compared to the untreated control cells. However, phosphorylation of $\gamma \mathrm{H} 2 \mathrm{AX}$ by $\mathrm{H}_{2} \mathrm{O}_{2}$ was almost inhibited in baicalein-pretreated cells (Figure 3B and C).

\section{Inhibition of $\mathrm{H}_{2} \mathrm{O}_{2}$-induced apoptosis by baicalein in RT4-D6P2T cells}

We next examined whether the protective effect of baicalein on the ROS production and DNA damage by $\mathrm{H}_{2} \mathrm{O}_{2}$ is related to the inhibition of apoptosis. The fluorescent images using DAPI staining show that the formation of chromatin condensation, which is observed in the apoptosis-induced cells, was greatly increased in the $\mathrm{H}_{2} \mathrm{O}_{2}$-treated RT4-D6P2T cells, and baicalein reliably weakened this effect (Figure 4A). In addition, the results of agarose gel electrophoresis showed that $\mathrm{H}_{2} \mathrm{O}_{2}$-induced DNA fragmentation, another evidence of the induction of apoptosis, was completely attenuated by the pretreatment of baicalein (Figure 4B). Furthermore, in cells treated with baicalein prior to $\mathrm{H}_{2} \mathrm{O}_{2}$ exposure, the inhibition of colony formation by $\mathrm{H}_{2} \mathrm{O}_{2}$ was significantly reduced (Figure $4 \mathrm{C}$ ), and baicalein pretreatment also reduced the increased frequency of apoptotic cells in $\mathrm{H}_{2} \mathrm{O}_{2}$-treated cells (Figure 4D).

\section{Inhibition of $\mathrm{H}_{2} \mathrm{O}_{2}$-induced mitochondrial dysfunction by baicalein in RT4-D6P2T cells}

To investigate the effect of baicalein on the mitochondrial dysfunction caused by oxidative stress, MMP values and intracellular ATP levels were evaluated. According to the results of $\mathrm{JC} 1$ staining, the loss of MMP was markedly increased in $\mathrm{H}_{2} \mathrm{O}_{2-}$ exposed cells, while this phenomenon was significantly reduced in baicalein-pretreated cells (Figure 5A). In addition, compared with cells cultured in normal medium, the concentration of ATP in cells exposed to $\mathrm{H}_{2} \mathrm{O}_{2}$ was significantly decreased (Figure $5 \mathrm{~B})$. However, the content of ATP in $\mathrm{H}_{2} \mathrm{O}_{2}$-treated cells in the presence of baicalein was maintained almost at the control level.

\section{Effects of baicalein on the alteration of the apoptosis regulatory genes by $\mathrm{H}_{2} \mathrm{O}_{2}$ in RT4-D6P2T cells}

Furthermore, we investigated the effect of baicalein on changes in apoptosis-regulating genes expression in $\mathrm{H}_{2} \mathrm{O}_{2}$-treated RT4-D6P2T cells. The immunoblotting results of Figure $6 \mathrm{~A}$ and $\mathrm{B}$ show that the expression of pro-apoptotic Bax was increased, whereas in $\mathrm{H}_{2} \mathrm{O}_{2}$-treated cells, the expression of anti-apoptotic Bcl-2 was decreased. Further, the expression of cytochrome $c$ in $\mathrm{H}_{2} \mathrm{O}_{2}$-stimulated cells was increased in the cytoplasmic fraction compared to the mitochondrial fraction, indicating that cytochrome $c$ was released from the mitochondria into the cytoplasm (Figure 6C and D). However, in the cells pretreated with baicalein, these changes were not observed. In addition, the expression of pro-caspase-9 and -3 was reduced in $\mathrm{H}_{2} \mathrm{O}_{2}$-treated cells, and the expression of truncated PARP, a representative substrate protein degraded by activated caspase-3, was increased, indicating that the intrinsic pathway was activated. In contrast, these changes by $\mathrm{H}_{2} \mathrm{O}_{2}$ 
treatment were relatively conserved in the baicaleinpretreated (Figure 7).

\section{Discussion}

Schwann cells are the main target cells of oxidative stress at the onset of neurodegenerative diseases, and several natural antioxidants have been reported to prevent functional damage of these cells by oxidative stress [27-31]. However, since the antioxidant efficacy of baicalein, a major flavonoid isolated from Radix Scutellariae, in Schwann cells has not yet been studied, this study investigated the effect of baicalein on cell injury by oxidative stress using the RT4-D6P2T cell model. Our results indicated that baicalein significantly protected RT4-D6P2T cells from oxidative stress, which was associated with the inhibition of ROS generation. We also demonstrated that baicalein inhibited DNA damage by oxidative stress, as evidenced by attenuation of $\mathrm{H}_{2} \mathrm{O}_{2}$-induced DNA tail formation and $\gamma \mathrm{H} 2 \mathrm{AX}$ phosphorylation. In addition, we confirmed through DAPI staining, agarose gel electrophoresis, and flow cytometry assays that baicalein significantly inhibited $\mathrm{H}_{2} \mathrm{O}_{2}$ induced apoptosis. These results suggest that inhibition of excessive ROS production by baicalein contributed to blocking of $\mathrm{H}_{2} \mathrm{O}_{2}$-induced proliferation reduction, DNA damage, and apoptosis in RT4-D6P2T Schwann cells.

Excessive ROS production by oxidative stress has been recognized to be one of the mechanisms leading to apoptosis, following DNA damage associated with mitochondrial dysfunction [32-34]. Apoptosis can be categorized into two pathways, generally mitochondria-dependent intrinsic and death receptor-mediated extrinsic apoptotic signaling pathways. Unlike the extrinsic pathway activated by the binding of apoptotic ligands to death receptors on cell membranes, the overload of ROS by oxidative stress results in the loss of MMP, which is considered to be a characteristic of the onset of the intrinsic apoptotic pathway [32,33]. At the same time, mitochondrial dysfunction due to excessive ROS production associated with the destruction of MMP causes an abnormality in the electron transport pathway of the mitochondrial respiratory chain [32-34]. The impairment of energy metabolism ultimately interferes with the production of intracellular ATP $[33,35]$. According to current studies, the levels of MMP values and ATP contents were significantly reduced in $\mathrm{H}_{2} \mathrm{O}_{2}$-treated RT4-D6P2T cells. However, they were significantly inhibited in the baicalein-pretreated cells, and were almost preserved at the control levels, indicating that mitochondrial dysfunction due to oxidative stress was blocked by baicalein.
A)

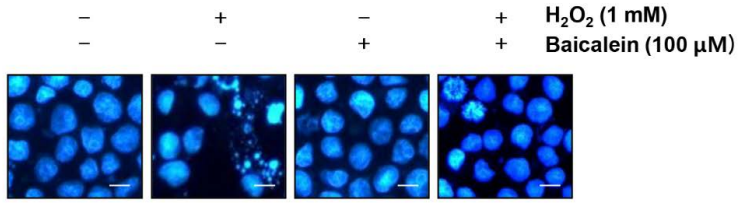

B)
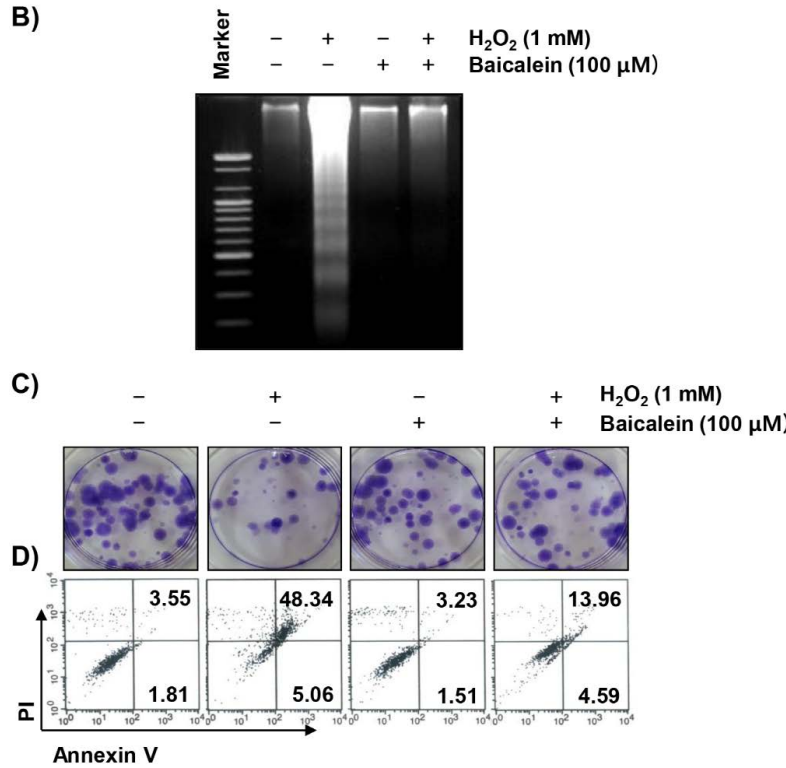

Figure 4. Suppression of $\mathrm{H}_{2} \mathrm{O}_{2}$-induced apoptosis by baicalein in RT4-D6P2T cells. Cells were treated with $100 \mu \mathrm{M}$ baicalein for $1 \mathrm{~h}$, and then stimulated with or without $1 \mathrm{mM} \mathrm{H} \mathrm{H}_{2}$ for $24 \mathrm{~h}$. (A) The cells were fixed and stained with DAPI solution. The stained nuclei were observed by fluorescence microscopy (original magnification, $\times 400$ ). Scale bars, $10 \mu \mathrm{m}$. (B) DNA fragmentation was analyzed by extracting genomic DNA, electrophoresis in a $1.5 \%$ agarose gel, and then visualizing by $\mathrm{EtBr}$ staining. (C) After treatment, the cells were further cultured for two weeks to form colonies. The cells were stained with a $0.1 \%$ purple-violet solution, and then imaged under inverted microscopy. Representative photographs are shown. (D) The cells were collected and stained with annexin- $\mathrm{V}$ and $\mathrm{Pl}$, and the percentages of apoptotic cells were then analyzed by flow cytometry. The results are the means of two independent experiments.

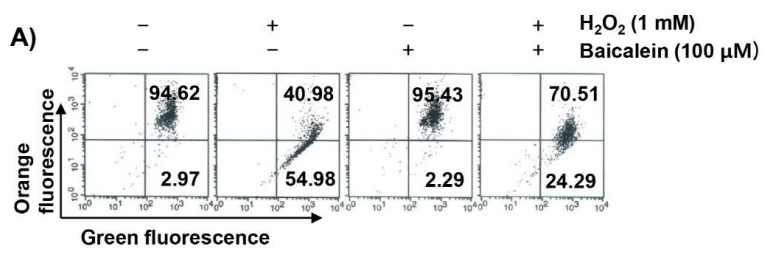

B)

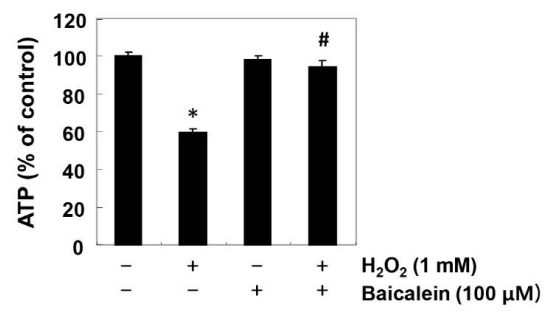

Figure 5. Prevention of $\mathrm{H}_{2} \mathrm{O}_{2}$-induced mitochondrial dysfunction by baicalein in RT4-D6P2T cells. Cells were treated with $100 \mu$ M baicalein for $1 \mathrm{~h}$, and then stimulated with or without $1 \mathrm{mM} \mathrm{H} \mathrm{H}_{2}$ for $24 \mathrm{~h}$. (A) The cells were collected and incubated with $10 \mu \mathrm{M} \mathrm{JC}-1$ for 20 min at $37^{\circ} \mathrm{C}$ in the dark. The values of MMP were evaluated by flow cytometry. The data are the means of the two different experiments. (B) To monitor the ATP production using a luminometer, a commercially available kit was used. The results are the mean \pm SD obtained from three independent experiments ( $* 00.05$ compared with the control group, $\# p<0.05$ compared with the $\mathrm{H}_{2} \mathrm{O}_{2}$-treated group). 
A)

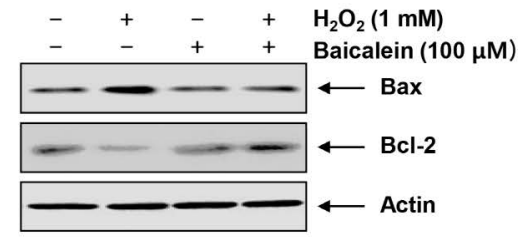

B)

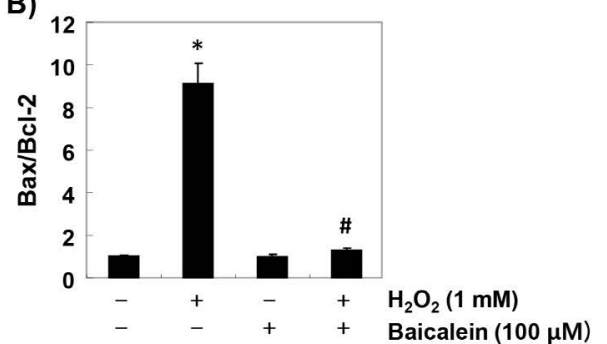

C)

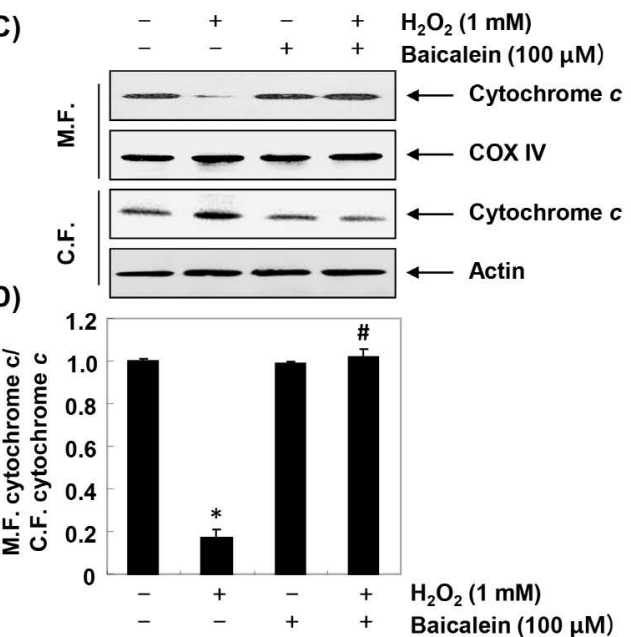

Figure 6. Effects of baicalein on $\mathrm{H}_{2} \mathrm{O}_{2}$-induced changes of Bax and $\mathrm{Bcl}-2$ expression in RT4-D6P2T cells. (A and C) Cells were treated with $100 \mu \mathrm{M}$ baicalein for $1 \mathrm{~h}$, and then stimulated with or without $1 \mathrm{mM} \mathrm{H}_{2} \mathrm{O}_{2}$ for $24 \mathrm{~h}$. The cellular proteins were separated by SDS-polyacrylamide gel electrophoresis, and then transferred to membranes. The membranes were probed with the indicated antibodies. Proteins were visualized using an ECL detection system. Actin was used as an internal control. (C) The mitochondrial and cytosolic proteins isolated from cells cultured under the same conditions were separated by SDS polyacrylamide gel electrophoresis, and transferred to the membranes. The membranes were probed with anti-cytochrome $c$ antibody. The proteins were visualized using an ECL detection system. Equal protein loading was confirmed by the analysis of COX VI and actin in each protein extract. (B and D) Bands were quantified using ImageJ and normalized to actin or COX IV, and the ratio was determined. Data are expressed as mean \pm SD. All experiments were repeated three times ( $\# p<0.05$ in comparison to the control group; ${ }^{*}<<0.05$ compared with the $\mathrm{H}_{2} \mathrm{O}_{2}$ group).

A)
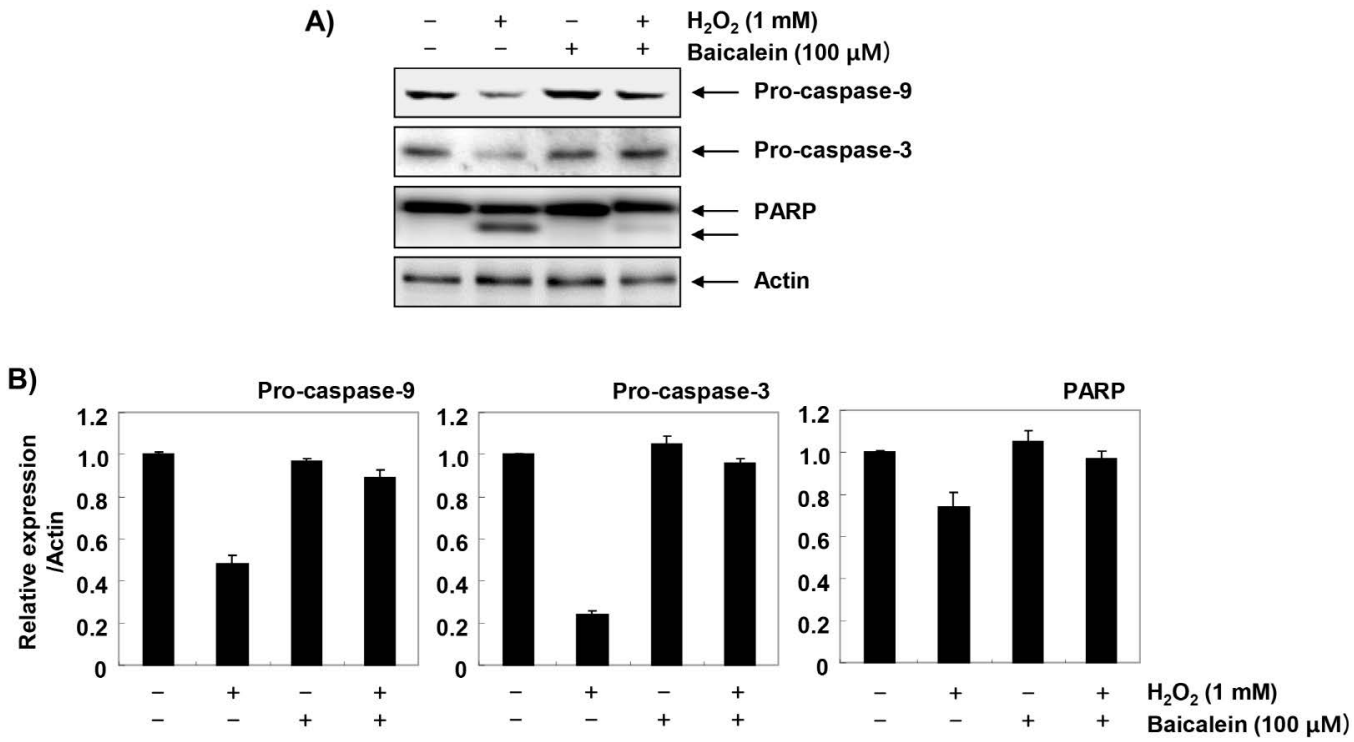

Figure 7. Effects of baicalein on $\mathrm{H}_{2} \mathrm{O}_{2}$-induced activation of caspases and degradation of PARP in RT4-D6P2T cells. (A) The cellular proteins extracted from cells grown under the same condition as in Fig. 6 were separated by SDS-polyacrylamide gel electrophoresis, and then transferred to membranes. The membranes were probed with the indicated antibodies. Proteins were visualized using an ECL detection system. Actin was used as an internal control. (B) The proteins were visualized using an ECL detection system. Equal protein loading was confirmed by the analysis of COX VI and actin in each protein extract. (B and $D$ ) Bands were quantified using Image and normalized to actin or COX IV, and the ratio was determined. Data are expressed as mean \pm SD. All experiments were repeated three times ( ${ }^{\#} p<0.05$ in comparison to the control group; $* p<0.05$ compared with the $\mathrm{H}_{2} \mathrm{O}_{2}$ group).

On the other hand, the loss of MMP enhances the release of death-promoting factors such as cytochrome $c$ from the mitochondria to the cytoplasm, and cytochrome $c$ in the cytoplasm forms apoptosomes by binding to apoptosis protein activation factor $1[36,37]$. Apoptosomes sequentially activate caspase-9, a potent stimulant of intrinsic apoptosis pathway. Activated caspase- 9 triggers activation of effector caspases such as caspase- 3 and
-7, which promotes degradation of a variety of substrate proteins, including PARP necessary for cell survival, and eventually induces apoptosis. In this process, Bcl-2 family proteins, which are composed of factors promoting and inhibiting apoptosis, also play an important role $[38,39]$. The pro-apoptotic proteins belonging to the Bcl-2 family members, such as Bax, migrate to the mitochondria, destroying the mitochondrial permeability, and opening the mitochondrial 
pores to release cytochrome $c$; while anti-apoptotic proteins, such as Bcl-2, act in reverse manner [38,39]. Therefore, the balance between pro-apoptotic proteins and anti-apoptotic proteins in Bcl-2 family members is considered to be a controlling factor of apoptosis induction. The results of this study show that $\mathrm{H}_{2} \mathrm{O}_{2}$-induced increase in $\mathrm{Bax} / \mathrm{Bcl}-2$ ratio and cytoplasmic release of cytochrome $c$ were effectively reversed by baicalein. In addition, decreased expression of pro-caspase- 9 and -3 by $\mathrm{H}_{2} \mathrm{O}_{2}$ treatment, which means they were activated, was restored to the control level by pretreatment with baicalein; and degradation of PARP, a biochemical hallmark of apoptosis, was also inhibited. These results imply that baicalein was able to weaken apoptosis through preservation of mitochondrial function in RT4-D6P2T Schwann cells. Although current results may provide a partial understanding of the antioxidant effects of baicalein, further evaluation using primary cultured Schwann cells and in vivo animal models is required. Based on these results, another study should be conducted to discuss metabolism as a functional dietary material of baicalein in human and physiological concentrations in the future.

In conclusion, the current results show that baicalein protects against the $\mathrm{H}_{2} \mathrm{O}_{2}$-induced loss of viability, ROS generation, DNA damage, and apoptosis in RT4-D6P2T Schwann cells. The beneficial effects of baicalein are closely related to the maintenance of energy metabolism, by preventing mitochondrial dysfunction. Although further studies between ROS generation inhibition and energy metabolism are needed, the present results suggest that baicalein has potential efficacy in the neuroprotection of peripheral nerves, by potentially protecting Schwann cells from oxidative stressmediated damage.

\section{Acknowledgement}

This research was supported by Basic Science Research Program through the National Research Foundation of Korea (NRF) grant funded by the Korea government (2018R1A2B2005705 and 2016R1A 5A2007009).

\section{Competing Interests}

The authors have declared that no competing interest exists.

\section{References}

1. Ino D, Iino M. Schwann cell mitochondria as key regulators in the development and maintenance of peripheral nerve axons. Cell Mol Life Sci. 2017;74:827-835.

2. Tully M, Shi R. New insights in the pathogenesis of multiple sclerosis-role of acrolein in neuronal and myelin damage. Int J Mol Sci. 2013;14:20037-20047.

3. Quintes S, Brinkmann BG. Transcriptional inhibition in Schwann cell development and nerve regeneration. Neural Regen Res. 2017;12:1241-1246.
4. Lehmann HC, Höke A. Use of engineered Schwann cells in peripheral neuropathy: Hopes and hazards. Brain Res. 2016;1638:97-104.

5. Castelnovo LF, Bonalume V, Melfi S, Ballabio M, Colleoni D, Magnaghi V. Schwann cell development, maturation and regeneration: a focus on classic and emerging intracellular signaling pathways. Neural Regen Res. 2017;12:1013-1023.

6. Chen $\mathrm{YL}$, Chen $\mathrm{KH}$, Yin TC, Huang $\mathrm{TH}$, Yuen CM, Chung SY, et al Extracorporeal shock wave therapy effectively prevented diabetic neuropathy. Am J Transl Res. 2015;7:2543-2560.

7. Jirsova K, Mandys V, Gispen WH, Bär PR. Cisplatin-induced apoptosis in cultures of human Schwann cells. Neurosci Lett. 2006;392:22-26.

8. Park CJ, Park SA, Yoon TG, Lee SJ, Yum KW, Kim HJ. Bupivacaine induces apoptosis via ROS in the Schwann cell line. J Dent Res. 2005;84:852-857.

9. Vincent AM, Brownlee M, Russell JW. Oxidative stress and programmed cell death in diabetic neuropathy. Ann N Y Acad Sci. 2002;959:368-383.

10. Fukunaga M, Miyata S, Liu BF, Miyazaki H, Hirota Y, Higo S, et al. Methylglyoxal induces apoptosis through activation of p38 MAPK in rat Schwann cells. Biochem Biophys Res Commun. 2004;320:689-695.

11. Carvalho LF, Silva AMF, Carvalho AA. The use of antioxidant agents for chemotherapy-induced peripheral neuropathy treatment in animal models. Clin Exp Pharmacol Physiol. 2017;44:971-979.

12. Brami C, Bao T, Deng G. Natural products and complementary therapies for chemotherapy-induced peripheral neuropathy: A systematic review. Crit Rev Oncol Hematol. 2016;98:325-334.

13. Oyenihi AB, Ayeleso AO, Mukwevho E, Masola B. Antioxidant strategies in the management of diabetic neuropathy. Biomed Res Int. 2015;2015:515042.

14. Zhao Q, Chen XY, Martin C. Scutellaria baicalensis, the golden herb from the garden of Chinese medicinal plants. Sci Bull (Beijing). 2016;61:1391-1398.

15. Gaire BP, Moon SK, Kim H. Scutellaria baicalensis in stroke management: nature's blessing in traditional Eastern medicine. Chin J Integr Med. 2014;20:712-720.

16. Li-Weber M. New therapeutic aspects of flavones: the anticancer properties of Scutellaria and its main active constituents wogonin, baicalein and baicalin. Cancer Treat Rev. 2009;35:57-68.

17. Cheng CS, Chen J, Tan HY, Wang N, Chen Z, Feng Y. Scutellaria baicalensis and cancer treatment: Recent progress and perspectives in biomedical and clinical studies. Am J Chin Med. 2018;46:25-54.

18. Tian Y, Li X, Xie H, Wang X, Xie Y, Chen C, et al. Protective mechanism of the antioxidant baicalein toward hydroxyl radical-treated bone marrow-derived mesenchymal stem cells. Molecules. 2018;23:223.

19. Bie B, Sun J, Guo Y, Li J, Jiang W, Yang J, et al. Baicalein: A review of its anti-cancer effects and mechanisms in hepatocellular carcinoma. Biomed Pharmacother. 2017;93:1285-1291.

20. Sowndhararajan K, Deepa P, Kim M, Park SJ, Kim S. Baicalein as a potent neuroprotective agent: A review. Biomed Pharmacother. 2017;95:1021-1032.

21. Choi EO, Cho EJ, Jeong JW, Park C, Hong SH, Hwang HJ, et al. Baicalein inhibits the migration and invasion of B16F10 mouse melanoma cells through inactivation of the PI3K/Akt signaling pathway. Biomol Ther (Seoul). 2017;25:213-221.

22. Choi EO, Jeong JW, Park C, Hong SH, Kim GY, Hwang HJ, et al. Baicalein protects $\mathrm{C} 6$ glial cells against hydrogen peroxide-induced oxidative stress and apoptosis through regulation of the Nrf2 signaling pathway. Int J Mol Med. 2016;37:798-806.

23. Kim HJ, Park C, Han MH, Hong SH, Kim GY, Hong SH, et al. Baicalein induces caspase-dependent apoptosis associated with the generation of ROS and the activation of AMPK in human lung carcinoma A549 cells. Drug Dev Res. 2016;77:73-86.

24. Gao Y, Snyder SA, Smith JN, Chen YC. Anticancer properties of baicalein: a review. Med Chem Res. 2016;25:1515-1523.

25. de Oliveira MR, Nabavi SF, Habtemariam S, Erdogan Orhan I, Daglia M, Nabavi SM. The effects of baicalein and baicalin on mitochondrial function and dynamics: A review. Pharmacol Res. 2015;100:296-308.

26. Collins AR, El Yamani N, Lorenzo Y, Shaposhnikov S, Brunborg G, Azqueta A. Controlling variation in the comet assay. Front Genet. 2014;5:359.

27. He B, Wu F, Fan L, Li XH, Liu Y, Liu YJ, et al. Carboxymethylated chitosan protects Schwann cells against hydrogen peroxide-induced apoptosis by inhibiting oxidative stress and mitochondria dependent pathway. Eur J Pharmacol. 2018;825:48-56.

28. Xue B, Wang L, Zhang Z, Wang R, Xia XX, Han PP, et al. Puerarin may protect against Schwann cell damage induced by glucose fluctuation. J Nat Med. 2017;71:472-481.

29. Yang X, Yao W, Shi H, Liu H, Li Y, Gao Y, et al. Paeoniflorin protects Schwann cells against high glucose induced oxidative injury by activating Nrf2/ARE pathway and inhibiting apoptosis. J Ethnopharmacol. 2016;185:361-369.

30. Ju DT, Kuo WW, Ho TJ, Paul CR, Kuo CH, Viswanadha VP, et al. Protocatechuic acid from Alpinia oxyphylla induces Schwann cell migration via ERK1/2, JNK and p38 activation. Am J Chin Med. 2015;43:653-665.

31. Yuan H, Zhang J, Liu H, Li Z. The protective effects of resveratrol on Schwann cells with toxicity induced by ethanol in vitro. Neurochem Int. 2013;63:146-153.

32. D'Autréaux B, Toledano MB. ROS as signalling molecules: mechanisms that generate specificity in ROS homeostasis. Nat Rev Mol Cell Biol. 2007;8:813-824.

33. Rigoulet M, Yoboue ED, Devin A. Mitochondrial ROS generation and its regulation: mechanisms involved in $\mathrm{H} 2 \mathrm{O} 2$ signaling. Antioxid Redox Signal. 2011;14:459-468 
34. Finkel T, Holbrook NJ. Oxidants, oxidative stress and the biology of ageing. Nature. 2000;408:239-247.

35. Valero T. Mitochondrial biogenesis: pharmacological approaches. Curr Pharm Des. 2014;20:5507-5509.

36. Wu CC, Bratton SB. Regulation of the intrinsic apoptosis pathway by reactive oxygen species. Antioxid Redox Signal. 2013;19:546-558.

37. Kadenbach B, Arnold S, Lee I, Hüttemann M. The possible role of cytochrome $c$ oxidase in stress-induced apoptosis and degenerative diseases. Biochim Biophys Acta. 2004;1655:400-408.

38. Kiraz Y, Adan A, Kartal Yandim M, Baran Y. Major apoptotic mechanisms and genes involved in apoptosis. Tumour Biol. 2016;37:8471-8486.

39. Lindsay J, Esposti MD, Gilmore AP. Bcl-2 proteins and mitochondria-specificity in membrane targeting for death. Biochim Biophys Acta. 2011;1813:532-539. 